\title{
Influence of upper-air conditions on glaciers in Scandinavia
}

\author{
L.A. RASMUSSEN, H. CONWAY \\ Department of Earth and Space Sciences, University of Washington, Seattle, WA 98195-1310, USA \\ E-mail: LAR@geophys.washington.edu
}

\begin{abstract}
A simple model using once-daily US National Centers for Environmental Prediction/US National Center for Atmospheric Research (NCEP/NCAR) re-analysis upper-air values estimates winter balance, summer balance and net balance at ten glaciers in Norway and two in Sweden with $0.37 \leq \mathbf{r}^{2} \leq \mathbf{0 . 9 0}$. The October-May Arctic Oscillation (AO), an index of sea-level pressure (SLP) in the Northern Hemisphere, correlates with winter balance and net balance with $0.09 \leq \mathbf{r}^{2} \leq 0.82$, lower than the model in all but 3 of the 24 cases. The October-May North Atlantic Oscillation (NAO), an SLP gradient in the North Atlantic, has lower correlations than the AO for all but 5 of the 24 cases. At all ten glaciers with records beginning before 1987, net balance became more positive after 1988, owing mainly to increased winter balance, with summer balance changing little. Although winter temperatures increased, they were still well below freezing, so the rain-snow division of the precipitation was only slightly affected. Increase in winter balance was due to increased precipitation caused by a change in atmospheric circulation, resulting in more frequent westerly flow concurrent with the warming. At $850 \mathrm{hPa}$, westerly flow is $\approx 2.5^{\circ} \mathrm{C}$ warmer than easterly flow; westerly flow warmed by $\approx 0.3^{\circ} \mathrm{C}$, easterly by $\approx 0.7^{\circ} \mathrm{C}$. Both the $\mathrm{AO}$ and $\mathrm{NAO}$, with which winter balance is positively correlated at all 12 glaciers, were more positive after 1988 .
\end{abstract}

\section{INTRODUCTION}

\section{Relation to previous work}

Pohjola and Rogers (1997) give an excellent survey of research on the response of glaciers in Scandinavia to meteorological conditions. One of the main findings is that whereas glaciers in most regions have rapidly lost mass over the past decade or two of pronounced global warming, those in Scandinavia have not. The other is that glacier mass balance in Scandinavia is largely controlled by atmospheric circulation over the North Atlantic.

One of the purposes of this study is to investigate the relation between seasonal mass-balance components and meteorological conditions in Scandinavia by applying a model that produces good results for glaciers in western North America. Another is to demonstrate the suitability of a major global database of upper-air conditions for modeling massbalance processes in Scandinavia. Yet another is to describe changes over the last half-century in mass balance and in upper-air conditions, with particular attention to why glaciers in Scandinavia have not lost mass during the recent period of strong global warming, unlike glaciers elsewhere in the world (Dyurgerov and Meier, 2000; Arendt and others, 2002).

\section{Mass-balance components}

The most commonly reported mass-balance information for a glacier is the interannual variation of mass change, which is expressed as the thickness change averaged over the entire glacier area, given in water equivalent meters. Two different time bases are customarily used: (1) the fixed-date method, usually from 1 October to 1 October in the Northern Hemisphere, is termed annual balance; and (2) the change from the time of minimum mass at the end of one summer to the time of minimum mass at the end of the following summer is termed net balance. The two methods give comparable results in northern temperate climates because the date of minimum mass is usually near 1 October and because the rate of mass change then is smaller than in either summer or winter. Published values often do not distinguish between the two time bases of interannual variations. Here they are referred to generically as net balance $b_{n}$.

Seasonal components are winter balance $b_{w}$, accounting for mass gain from the beginning of the balance year until the maximum of mass, usually late the following spring, and summer balance $b_{\mathrm{s}}$, accounting for mass loss from then until the end of the balance year. Winter balance is the resultant difference between a large amount of accumulation and a small amount of ablation, whereas summer balance is the resultant difference between a large amount of ablation and a small amount of accumulation. The three components are related simply by

$$
b_{\mathrm{n}}=b_{\mathrm{w}}+b_{\mathrm{s}}
$$

with $b_{\mathrm{s}}$ defined to be a negative quantity. All three components are identified by the calendar year in which the balance year ends.

\section{DATABASES}

Glaciers in Norway are monitored by the Norwegian Water Resources and Energy Directorate (NVE), and in Sweden by Stockholm University. Seasonal mass balances through 2002 are given by Kjøllmoen (2003). Values for glaciers in Sweden were supplied by P. Jansson (personal communication, 2003). Records that began before 1990 (ten in Norway, two in Sweden) are used in this study (Fig. 1; Table 1).

US National Centers for Environmental Prediction/US National Center for Atmospheric Research (NCEP/NCAR) reanalysis data (Kalnay and others, 1996) for the period 194899 were obtained from NCAR in June 2002. The International Geophysical Year (1957/58) inspired increases in the quantity and quality of radiosonde data. Observation times changed on 1 June 1957 from 0300 and 1500 UTC, to 0000 and 1200 UTC (Angell, 1988; Kistler and others, 2001). Severe biases in the humidity record prior to about 1975 occurred during the evolution of instrumentation and 
recording methods (section 4 of Rasmussen and others, 2001), including some due to changes in sensor design and one due to inadequate shielding from solar radiation, which caused aberrantly low daytime readings. Thus, values at only 0000 UTC, which comes at night in Scandinavia, are used here to lessen the effects of inhomogeneities in the historical humidity record.

The Arctic Oscillation (AO; Thompson and Wallace, 2000 ) is the leading empirical orthogonal function of the sea-level pressure (SLP) field in the Northern Hemisphere. In its warm phase (positive index), there is a negative anomaly in the Arctic, and a positive one at mid-latitudes, producing strong westerlies over the North Atlantic. In its cool phase (negative index), the anomalies are reversed and the westerly regime is much weaker. Monthly values for the period 1899-2001 are tabulated by D. Thompson (www.atmos.colostate.edu/ao/Data/ao_index.html).

The North Atlantic Oscillation (NAO; Hurrell 1995; Jones and others 1997) is the normalized SLP gradient between two stations, one in Iceland, the other in the Azores or in Spain. It has positive correlation with the AO. Monthly values for the period 1825-2000 were obtained on 15 December 2003 from www.cru.uea.ac.uk/ftpdata/nao.dat.

\section{ESTIMATING MASS BALANCE FROM NCEP/NCAR DATA}

The method used on Scandinavian glaciers is detailed in Rasmussen and Conway $(2001,2003)$. The model uses daily NCEP/NCAR values of wind and humidity at one level in the atmosphere, and temperature at two levels. Precipitation flux $F$ is defined as the product $U R H$, in which $0 \leq \mathrm{RH} \leq 1$ is relative humidity and $U$ is the component of the $850 \mathrm{hPa}$ wind in a specified critical direction $\phi^{\prime}$; if $U \leq 0, F$ is taken to be zero. Alternative formulations tested during development of the model (Rasmussen and Conway 2001; Rasmussen and others 2001; Hayes and others, 2002) showed that scaling $U$ by $\mathrm{RH}$ gave better results than scaling by the absolute humidity.

Snow flux $f$ at a particular site equals $F$ if the temperature interpolated at its altitude $z_{1}$ between the 850 and $700 \mathrm{hPa}$ levels is less than $+2{ }^{\circ} \mathrm{C}$, and is zero if greater. Both $F$ and $f$

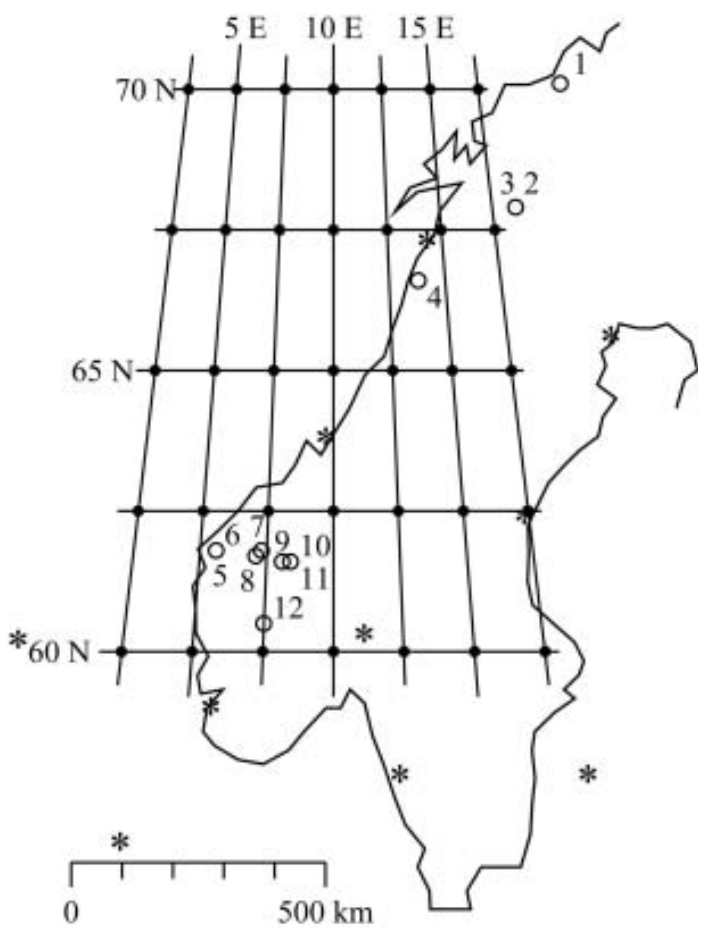

Fig. 1. Glaciers (open circles; see Table 1 for names), NCEP/NCAR re-analysis gridpoints (solid circles) and radiosonde stations $\left(^{*}\right)$.

are in units of meters per second. Winter balance is estimated from

$$
b_{\mathrm{w}}^{*}=\alpha_{\mathrm{w}} \bar{f}_{\mathrm{w}}+\gamma_{\mathrm{w}}
$$

in which $\bar{f}_{\mathrm{w}}$ is the October-May average of $f$. Summer balance is estimated from

$$
b_{\mathrm{s}}^{*}=\alpha_{\mathrm{s}} \bar{f}_{\mathrm{s}}+\beta_{\mathrm{s}} \bar{T}_{2}+\gamma_{\mathrm{s}}
$$

in which the June-September average of $f$ is $\bar{f}_{\mathrm{s}}$ and that of temperature interpolated at altitude $Z_{2}$ between the 850 and $700 \mathrm{hPa}$ levels, considering only $T>0{ }^{\circ} \mathrm{C}$, is $\bar{T}_{2}$. Altitudes $Z_{1}$ and $z_{2}$ are taken to be approximate altitudes of the glacier terminus and equilibrium line. A refined version of the model would use data from additional levels in the

Table 1. Model results $\left(\% r^{2}\right)$. Period modeled from $t_{0}$ through 1999, but excluding 1994 and 1995 at glacier 1. The model (Equations (2) and (3)) uses critical direction $\phi^{\prime}$ and altitudes $z_{1}$ to calculate accumulation, and $z_{2}$ to calculate ablation. October-May AO and NAO results from linear correlation with indicated balance component. All $r^{2}$ significant at $99 \%$ except NAO $b_{\mathrm{w}}$ for glaciers 1,3 and 4 ; NAO $b_{\mathrm{n}}$ for

\begin{tabular}{|c|c|c|c|c|c|c|c|c|c|c|c|}
\hline \multirow[t]{2}{*}{ Glacier } & \multirow[b]{2}{*}{$t_{0}$} & \multirow[b]{2}{*}{$Z_{1}$} & \multirow[b]{2}{*}{$z_{2}$} & \multirow[b]{2}{*}{$\phi^{\prime}$} & \multicolumn{3}{|c|}{ Model } & \multicolumn{2}{|c|}{$\mathrm{AO}$} & \multicolumn{2}{|c|}{$\mathrm{NAO}$} \\
\hline & & & & & $b_{\mathrm{w}}$ & $b_{\mathrm{s}}$ & $b_{\mathrm{n}}$ & $b_{\mathrm{w}}$ & $b_{\mathrm{n}}$ & $b_{\mathrm{w}}$ & $b_{\mathrm{n}}$ \\
\hline 1. Langfjordjøkelen & 1989 & 350 & 850 & $276^{\circ}$ & 90 & 55 & 87 & 33 & 11 & 1 & 1 \\
\hline 2. Storglaciären & 1949 & 1200 & 1500 & $275^{\circ}$ & 38 & 72 & 56 & 52 & 38 & 18 & 13 \\
\hline 3. Rabots glaciär & 1982 & 1100 & 1300 & $286^{\circ}$ & 65 & 59 & 65 & 63 & 53 & 17 & 40 \\
\hline 4. Engabreen & 1970 & 300 & 1000 & $298^{\circ}$ & 73 & 55 & 72 & 39 & 42 & 4 & 16 \\
\hline 5. Ålfotbreen & 1963 & 950 & 1150 & $250^{\circ}$ & 76 & 49 & 77 & 67 & 67 & 52 & 54 \\
\hline 6. Hansebreen & 1986 & 1000 & 1150 & $243^{\circ}$ & 71 & 49 & 50 & 59 & 40 & 81 & 69 \\
\hline 7. Austdalsbreen & 1988 & 1200 & 1400 & $264^{\circ}$ & 80 & 67 & 80 & 72 & 82 & 52 & 57 \\
\hline 8. Nigardsbreen & 1962 & 800 & 1500 & $262^{\circ}$ & 56 & 58 & 65 & 56 & 50 & 44 & 35 \\
\hline 9. Storbreen & 1949 & 1500 & 1700 & $246^{\circ}$ & 63 & 66 & 56 & 54 & 39 & 25 & 22 \\
\hline 10. Hellstugubreen & 1962 & 1500 & 1850 & $219^{\circ}$ & 47 & 74 & 63 & 37 & 26 & 28 & 27 \\
\hline 11. Gråsubreen & 1962 & 1900 & 2150 & $192^{\circ}$ & 37 & 78 & 63 & 20 & 9 & 22 & 15 \\
\hline 12. Hardangerjøkulen & 1963 & 1100 & 1600 & $276^{\circ}$ & 65 & 53 & 68 & 56 & 59 & 42 & 51 \\
\hline
\end{tabular}
glaciers 1, 2 and 4; and $\mathrm{AO} b_{\mathrm{n}}$ for glacier 11; all significant at 95\% except NAO $b_{\mathrm{w}}$ for glaciers 1 and 4 and $b_{\mathrm{n}}$ for glacier 1 
Table 2. Sensitivity (mw.e. $\mathrm{a}^{-1}$ ) of calculated balance to hypothetical $1{ }^{\circ} \mathrm{C}$ warming $\Delta T$ or $10 \%$ increase $\Delta F$ in precipitation flux, both applied uniformly throughout the year

\begin{tabular}{lcccc}
\hline Glacier & \multicolumn{5}{c}{$\Delta T$} & & $\Delta F$ \\
& $b_{\mathrm{w}}$ & $b_{\mathrm{s}}$ & $b_{\mathrm{n}}$ & $b_{\mathrm{n}}$ \\
\hline 1. Langfjordjøkelen & -0.21 & -0.32 & -0.53 & 0.20 \\
2. Storglaciären & -0.04 & -0.34 & -0.38 & 0.13 \\
3. Rabots glaciär & -0.06 & -0.24 & -0.30 & 0.16 \\
4. Engabreen & -0.34 & -0.57 & -0.91 & 0.35 \\
5. Ålfotbreen & -0.45 & -0.56 & -1.01 & 0.41 \\
6. Hansebreen & -0.41 & -0.45 & -0.86 & 0.36 \\
7. Austdalsbreen & -0.16 & -0.46 & -0.62 & 0.32 \\
8. Nigardsbreen & -0.11 & -0.48 & -0.59 & 0.24 \\
9. Storbreen & -0.07 & -0.35 & -0.42 & 0.15 \\
10. Hellstugubreen & -0.06 & -0.42 & -0.48 & 0.13 \\
11. Gråsubreen & -0.03 & -0.70 & -0.73 & 0.12 \\
12. Hardangerjøkulen & -0.22 & -0.42 & -0.64 & 0.22 \\
& & & & \\
\hline
\end{tabular}

atmosphere, so that extrapolation below the $850-700 \mathrm{hPa}$ layer could be avoided. Critical direction $\phi^{\prime}$ is determined empirically along with the best-fitting linear regression coefficients in Equations (2) and (3). The estimate of net balance is taken to be $b_{\mathrm{n}}^{*}=b_{\mathrm{w}}^{*}+b_{\mathrm{s}}^{*}$.

Goodness of fit is expressed by the coefficient of determination

$$
r^{2}=1-\left(\frac{r m s}{\sigma}\right)^{2}
$$

Here rms is the root mean square of the differences between the model estimates $b^{*}$ and the measured values $b$, and $\sigma$ is the standard deviation of $b$.

Upper-air conditions are taken from the NCEP/NCAR reanalysis gridpoint nearest the glacier. The gridpoint used and values of the model parameters $\phi^{\prime}, z_{1}$ and $z_{2}$ are given for each glacier in Table 1. Model results are only weakly sensitive to values of the model parameters as well as to the period of days over which the averages are formed. Because upper-air conditions are strongly correlated from gridpoint to gridpoint, the regression coefficients adjust to accommodate most of the differences if another gridpoint is used instead of the nearest one, so the results are not strongly sensitive to which one is used. Development of the model is detailed in Rasmussen and Conway (2001, 2003).

\section{RESULTS}

The model estimates $b_{\mathrm{w}}, b_{\mathrm{s}}$ and $b_{\mathrm{n}}$ at the 12 glaciers in Scandinavia (Table 1 ) with results comparable to those at four glaciers in western North America over similar periods of record, where $r^{2}$ ranged between 0.42 and 0.79 (Rasmussen and Conway, 2004). It generally estimates $b_{\mathrm{w}}$ better than $b_{\mathrm{s}}$ for more maritime glaciers in Scandinavia, and $b_{\mathrm{s}}$ better than $b_{\mathrm{w}}$ for more continental glaciers. In 21 of the 24 cases, the model estimates $b_{\mathrm{w}}$ and $b_{\mathrm{n}}$ better than do correlations with $\mathrm{AO}$, which in turn do better than correlations with NAO in 19 of the 24 cases. Nesje and others (2000) found comparable NAO correlations for $b_{\mathrm{w}}$ and $b_{\mathrm{n}}$. By contrast, the Pacific Decadal Oscillation, a

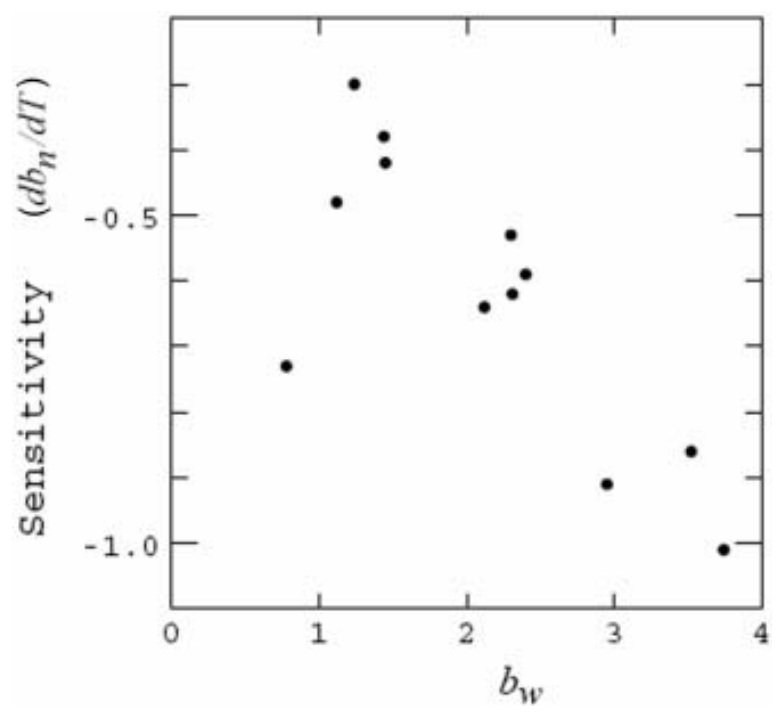

Fig. 2. Sensitivity of net balance $b_{\mathrm{n}}$ to $1{ }^{\circ} \mathrm{C}$ warming as a function of mean precipitation, approximated here by observed mean winter balance $b_{w}$. The outlier is Gråsubreen, the most continental glacier.

measure of sea surface temperature (SST) in the North Pacific, has much lower correlation with glacier balances in western North America (Rasmussen and Conway, 2004) than the $\mathrm{AO}$ and $\mathrm{NAO}$ have with glacier balances in Scandinavia.

Correlations of $b_{\mathrm{s}}$ with both $\mathrm{AO}$ and NAO are negligible at all 12 glaciers. Pohjola and Rogers (1997) found comparable correlations of NAO with $b_{\mathrm{s}}$ at Storglaciären, Rabots, Engabreen and Storbreen. They showed that the Norwegian Sea index they devised (pressure difference between Valentia, Ireland, and Vardø, Norway) correlates better than NAO with both $b_{\mathrm{w}}$ and $b_{\mathrm{s}}$ at the four glaciers.

Results for Storglaciären $b_{\mathrm{w}}$ are disappointing and somewhat enigmatic. Using upper-air data from the gridpoint at $65^{\circ} \mathrm{N}, 10^{\circ} \mathrm{E}$ with $\phi^{\prime}=272^{\circ}$ gave $r^{2}=0.60$, compared with 0.38 using the nearest gridpoint. Holmlund (1987) found that over $1945-86$ the correlation of $b_{\mathrm{n}}$ with June-August $T$ at Karesuando $(170 \mathrm{~km}$ northeast of the glacier, at $327 \mathrm{~m})$ was $r=-0.80$, with September-May precipitation there was $r=+0.42$, and with both combined was $|r|=0.84$.

Lie and others (2003) used May-September temperature and October-April precipitation at weather stations near the glaciers to model net balance $b_{\mathrm{n}}$. They obtained $r^{2}$ values of 0.64 for Ålfotbreen over 1963-96, 0.66 for Gråsubreen over 1962-96, 0.67 for Nigardsbreen over 1965-88, and 0.71 for Storbreen over 1960-96. Oerlemans and Reichert (2000) found for Nigardsbreen $b_{\mathrm{n}}$ over 1962-95 that meteorological measurements at Bergen (near the coast $170 \mathrm{~km}$ south-southwest) gave $r^{2}=0.46$, and measurements at three stations near the glacier gave 0.58; upper-air data from the European Centre for Medium-Range Weather Forecasts gave 0.72 over 1979-93. Jóhannesson and others (1995) using a 13-parameter degree-day model obtained $r^{2}=0.48$ for $b_{\mathrm{w}}$ and 0.62 for $b_{\mathrm{s}}$ at Nigardsbreen over 196581 and 1984-90.

Sensitivity of calculated $b_{\mathrm{w}}, b_{\mathrm{s}}$ and $b_{\mathrm{n}}$ to hypothetical warming or increased precipitation $\Delta F$ is shown in Table 2. Sensitivity to both is larger at maritime glaciers (4-6) than at the others, as noted also by Oerlemans and Fortuin (1992) and Laumann and Reeh (1993). The effect of $\Delta F$ on $b_{\mathrm{s}}$ is small, so the effect on $b_{\mathrm{n}}$ is due almost entirely to that on $b_{\mathrm{w}}$. 


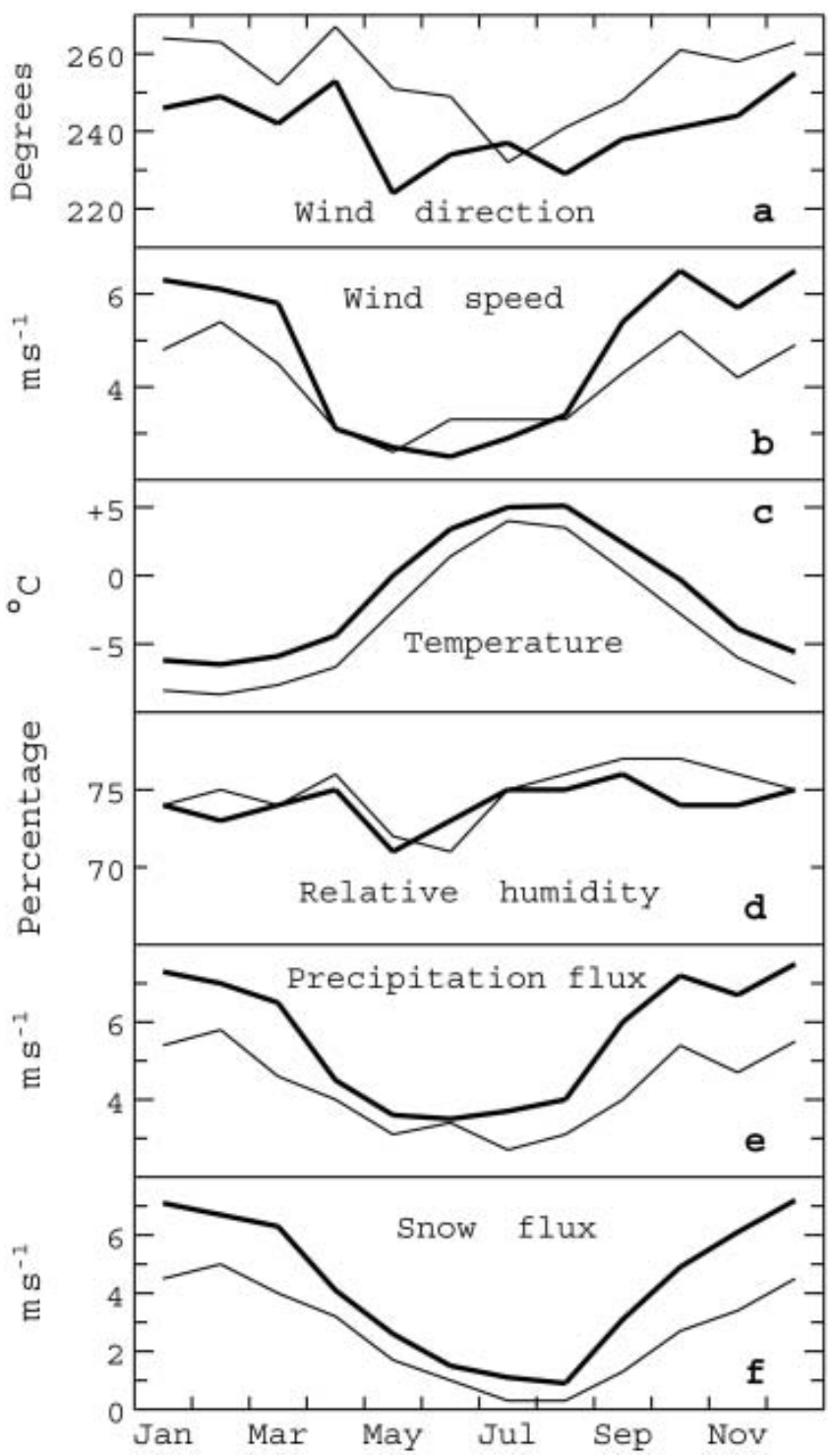

Fig. 3. Seasonal variation of mean $850 \mathrm{hPa}$ conditions, 1960-99, at two NCEP/NCAR re-analysis gridpoints: $67.5^{\circ} \mathrm{N}, 12.5^{\circ} \mathrm{E}$ (light curve) and $62.5^{\circ} \mathrm{N}, 7.5^{\circ} \mathrm{E}$ (heavy curve). (a) Wind direction; (b) wind speed; (c) temperature; (d) $\mathrm{RH}$; (e) precipitation flux; and (f) snow flux. Snow flux at $67.5^{\circ} \mathrm{N}, 12.5^{\circ} \mathrm{E}$ is calculated for altitude $300 \mathrm{~m}$, and snow flux at $62.5^{\circ} \mathrm{N}, 7.5^{\circ} \mathrm{E}$ for $1500 \mathrm{~m}$.

Sensitivities to temperature and precipitation are comparable to those found by other analyses. Holmlund and others (1996, fig. 5), using observations at the glacier, found a sensitivity of Storglaciären $b_{\mathrm{s}}$ to mean June-August temperature of $-0.4 \mathrm{~m}^{\circ} \mathrm{C}^{-1}$. Oerlemans (1992), using an energy-balance model, found $b_{\mathrm{n}}$ sensitivities to annual temperature of $-1.11 \mathrm{~m}^{\circ} \mathrm{C}^{-1}$ for Alfotbreen, $-0.88 \mathrm{~m}^{\circ} \mathrm{C}^{-1}$ for Nigardsbreen and $-0.72 \mathrm{~m}^{\circ} \mathrm{C}^{-1}$ for Hellstugubreen. Using a degree-day model for the same three glaciers, Laumann and Reeh (1993, equation (3)) found $b_{\mathrm{n}}$ sensitivities of, respectively, $-1.10,-0.60$ and $-0.54 \mathrm{~m}^{\circ} \mathrm{C}^{-1}$, and for a $10 \%$ increase in annual precipitation $+0.39,+0.23$ and $+0.14 \mathrm{~m}$. At the same three glaciers, Nesje and others (2000), using records from nearby weather stations, found values of, respectively, $-1.13,-0.68$ and $-1.11 \mathrm{~m}^{\circ} \mathrm{C}^{-1}$ and $+0.50,+0.26$ and $+0.02 \mathrm{~m}$, while for Storglaciären, Storbreen and Hardangerjøkulen they found, respectively, $-0.88,-1.13$ and $-0.71 \mathrm{~m}^{\circ} \mathrm{C}^{-1}$ and $+0.14,+0.07$ and

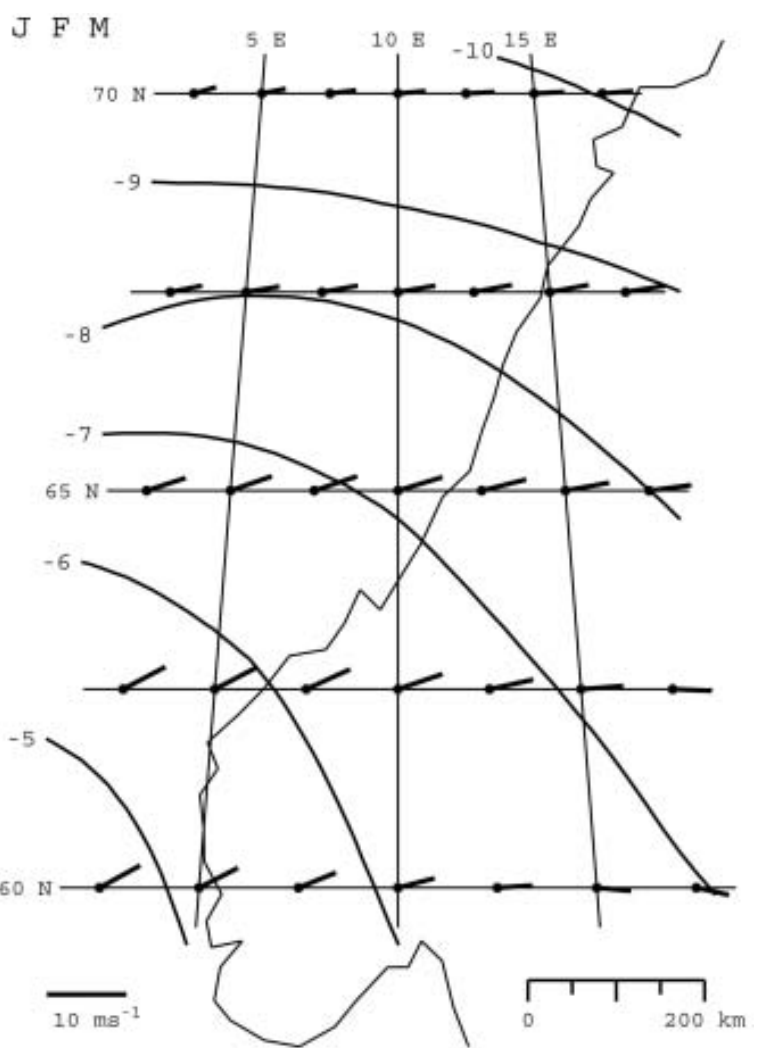

Fig. 4. Mean January-March $850 \mathrm{hPa}$ wind and temperature, 196099. The line emanates from the gridpoint in the downstream wind direction with its length proportional to the speed.

$+0.26 \mathrm{~m}$. As found by Oerlemans and Fortuin (1992) in a study of 12 glaciers in Eurasia and North America, the sensitivity $\mathrm{d} b_{\mathrm{n}} / \mathrm{d} T$ increases with mean annual precipitation, which is approximated here (Fig. 2) by mean winter balance $b_{\mathrm{w}}$.

\section{UPPER-AIR CLIMATOLOGY}

Wind at $850 \mathrm{hPa}$ is generally southwesterly throughout the year, with a pronounced winter maximum of speed (Fig. 3). In winter over Scandinavia the mean 1960-99 direction of the $850 \mathrm{hPa}$ wind is westerly, and the temperature gradient is south-southwestward (Fig. 4). In summer the mean direction is southwesterly, and the temperature gradient is southsoutheastward (Fig. 5). In winter, the percentage value of $\mathrm{RH}$ varies from the high 70s over the sea to the mid-60s inland, and in summer from the high 70s in the northern part to the low 70s in the southern part.

Over the entire year, the prevailing wind direction at $850 \mathrm{hPa}$ is westerly (Fig. 6). The westerly wind is much stronger, warmer and more moist than the easterly wind, and, in combination with nearly uniformly high $\mathrm{RH}$, this produces a winter maximum of precipitation flux $F$ from the prevailing direction. The seasonal variation of temperature accentuates the variation of $F$ to produce an even sharper summer minimum of snow flux $f$ (Fig. 3 ).

\section{TRENDS}

At all ten glaciers with records beginning by 1986 (Table 1 ), both $b_{\mathrm{n}}$ and $b_{\mathrm{w}}$ are more positive over 1989-2001 than 


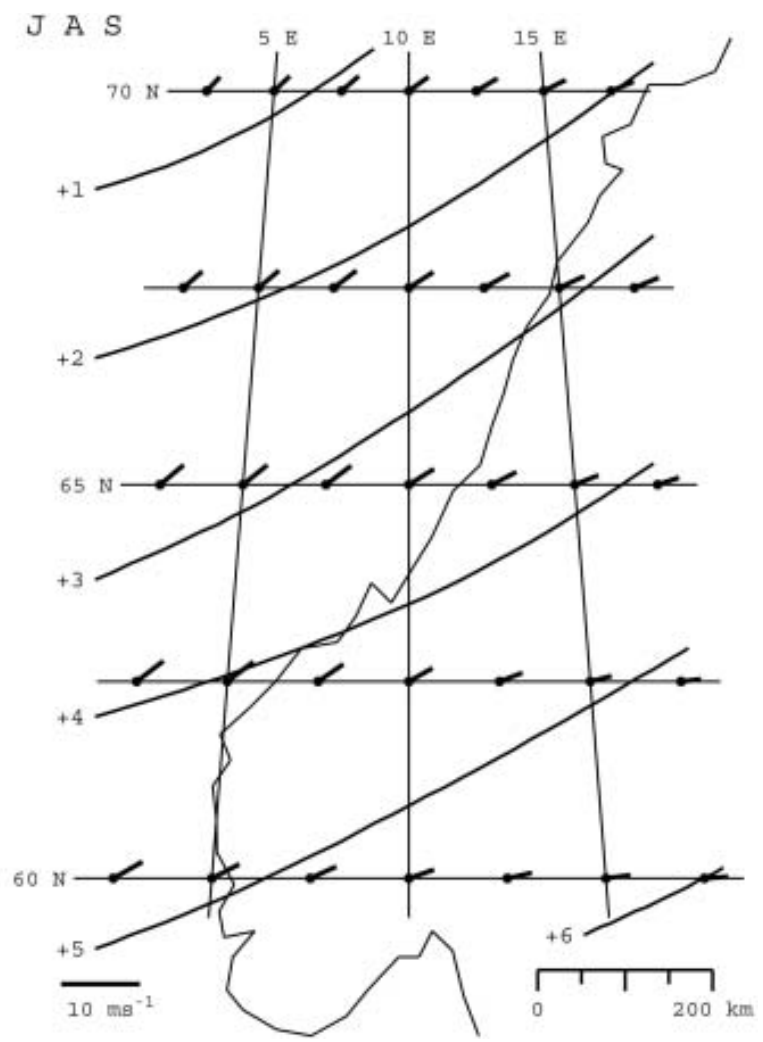

Fig. 5. Same as Figure 4, but for July-September.

before. As noted by Hagen (1996), $b_{\mathrm{n}}$ increased from 1988 to 1993 at Storglaciären and until 1994 at Engabreen and Nigardsbreen. Holmlund and others (1996) attribute increased $b_{\mathrm{n}}$ at Storglaciären until 1995 mainly to increased winter precipitation. Increases in $b_{\mathrm{n}}$ since 1988 were the result of large increases in $b_{\mathrm{w}}$, while $b_{\mathrm{s}}$ changed little.

The shift after 1988 is illustrated for Storbreen in Figure 7. Although winter temperature at the altitude of the glacier increased, it did not appreciably rob accumulation by shifting much precipitation from snow to rain, as warming did in western North America (Rasmussen and Conway, 2004) and over the Patagonia icefields (Rasmussen and others, in press). Winters at Storbreen are so cold that warming did not move much of the temperature distribution to above the critical $+2{ }^{\circ} \mathrm{C}$. Mean temperature during westerly $\left(U>0\right.$ for $\left.\phi^{\prime}=246^{\circ}\right)$ flow increased from -4.2 to $-3.9^{\circ} \mathrm{C}$, and the mean snow ratio $f / F$ only decreased from 0.91 to 0.90 . Increase in precipitation amount overwhelmed the slight decline in $f / F$.

Total $1500 \mathrm{~m}$ warming at $62.5^{\circ} \mathrm{N}, 7.5^{\circ} \mathrm{E}$ in winter was apparently the result of two effects. One, as reflected by the change in winter $\mathrm{AO}$ and $\mathrm{NAO}$, was increase in the incidence of westerly flow, which on average is $2.5^{\circ} \mathrm{C}$ warmer than easterly $(U \leq 0)$ flow (Fig. 6). The other was warming of both westerly flow $\left(0.3^{\circ} \mathrm{C}\right)$ and easterly flow $\left(0.7^{\circ} \mathrm{C}\right)$. The incidence of westerly flow increased after 1988 from $72.5 \%$ to $77.5 \%$ of winter days. Its strength also increased, resulting in an increase of the mean precipitation flux $F$ from 4.8 to $5.6 \mathrm{~m} \mathrm{~s}^{-1}$. Mass balance over 2001-03, however, became more negative at both maritime and continental glaciers in Norway owing to drier winters and warmer summers (Andreassen and others, 2005).

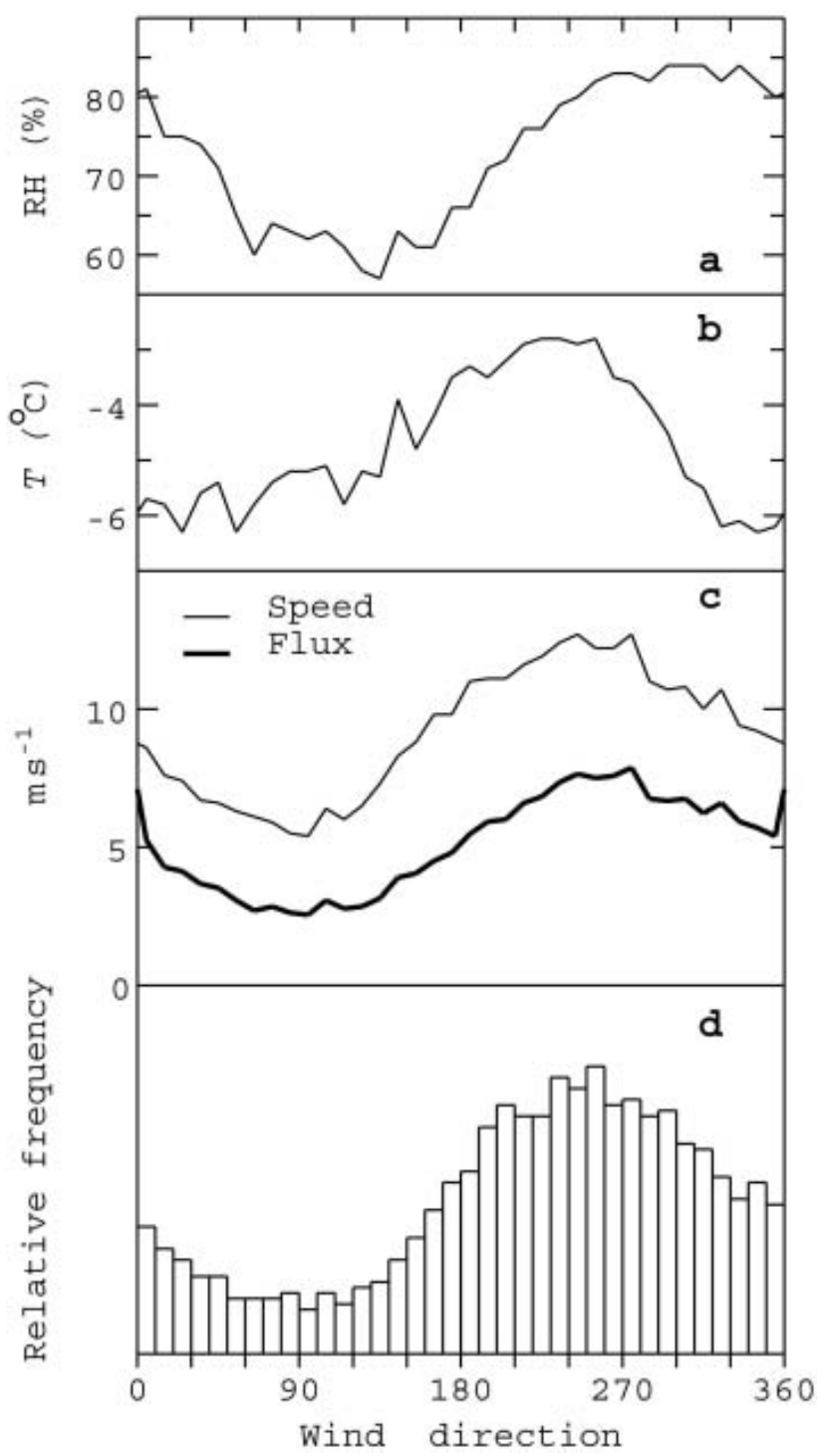

Fig. 6. Mean annual $850 \mathrm{hPa}$ values, 1960-99, as a function of wind direction at $62.5^{\circ} \mathrm{N}, 7.5^{\circ} \mathrm{E}$. (a) $\mathrm{RH}$; (b) temperature; (c) wind speed and flux; and (d) relative frequency. The flux is $\mathrm{RH}$ times the wind speed when $T<+2{ }^{\circ} \mathrm{C}$.

\section{CONCLUSIONS}

Mass gain by glaciers in Scandinavia during recent global warming is apparently the result of changes in mean atmospheric circulation over the North Atlantic that accompanied the warming. Unlike other regions, where winter warming shifts an appreciable amount of precipitation from snow to rain, over Scandinavia winter temperatures are so low that the warming shifted only a small amount. Increase in $b_{\mathrm{n}}$ is due mainly to increase in $b_{\mathrm{w}}$ resulting from increase in winter precipitation produced by the change in atmospheric circulation.

Although seasonal variation of large-scale patterns of SLP is indicative of mean atmospheric circulation, upper-air conditions in the vicinity of a glacier have a more direct and immediate effect. Their temporal variability better matches that of the two mass-balance processes, accumulation and ablation. Principal climatological variables pertinent to mass-balance processes are winter precipitation, winter temperature and summer temperature. The first two control mainly accumulation, the third mainly ablation. Because of 


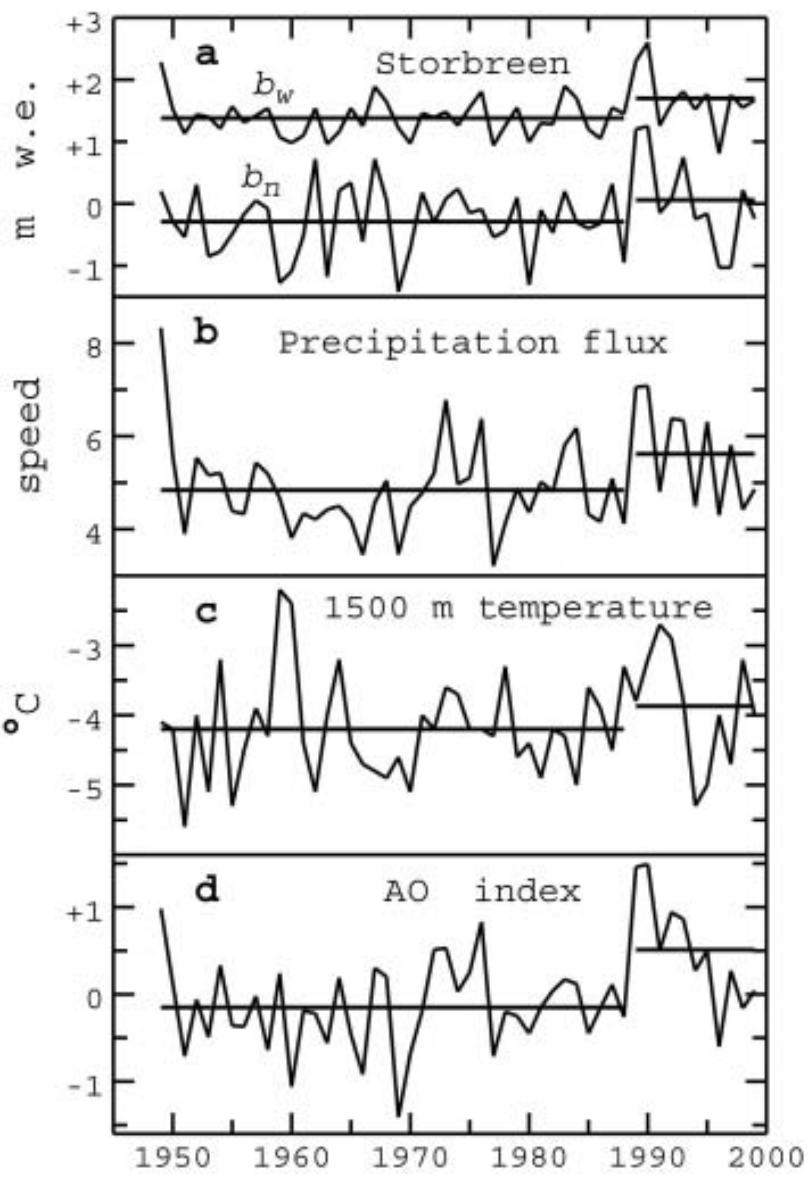

Fig. 7. Time series of Storbreen mass balance and relevant meteorological variables, showing mean values for the periods 1949-88 and 1989-99. (a) Winter balance and net balance; (b) $850 \mathrm{hPa}$ precipitation flux $F$; (c) $1500 \mathrm{~m}$ temperature $\left({ }^{\circ} \mathrm{C}\right)$ when $F>0$; and (d) AO index. (b) and (c) are from NCEP/NCAR gridpoint $62.5^{\circ} \mathrm{N}, 7.5^{\circ} \mathrm{E} ;(\mathrm{b}-\mathrm{d})$ are October-May averages.

non-linearities in the relations between meteorological conditions and the two processes, seasonal averages of large-scale patterns of SLP or SST generally do not correlate as well with seasonal totals of accumulation or ablation or, thus, with mass-balance components $b_{\mathrm{w}}$ or $b_{\mathrm{s}}$ or their sum $b_{\mathrm{n}}$.

Determining numerical values for regression coefficients in the model (Equations (2) and (3)), as well as critical direction $\phi^{\prime}$ and altitudes $z_{1}$ and $z_{2}$, requires a mass-balance record. In the absence of a record, rough estimates $\left(\phi^{\prime}\right.$ in the onshore direction, $z_{1}$ low on the glacier, and $z_{2}$ near the middle of it) permit forming time series of the snow fluxes $\bar{f}_{\mathrm{w}}$ and $\bar{f}_{\mathrm{s}}$ and temperature $\bar{T}_{2}$ from the meteorological database. Relative changes in these variables will give a qualitative indication of relative changes in mass-balance components.

One of the great advantages of the model is that it uses a database that is global in extent, has daily or better temporal resolution, is free from missing observations and is maintained as an integral part of a major scientific enterprise. Another is that in using upper-air values it avoids situations in which low-altitude weather stations are blanketed by lowlying cloud while glaciers at higher altitude are in clear conditions. The accuracy with which the model estimates glacier mass-balance components is comparable to that of other methods.

\section{ACKNOWLEDGEMENTS}

This work was funded by US National Science Foundation grant OPP-0240861 and NASA grant 1215388. Valuable comments by J. Oerlemans led to a much improved paper. We thank E. Recker for extracting reanalysis data from NCAR and R. Ludwin for supplying coastline coordinates.

\section{REFERENCES}

Andreassen, L.M., H. Elvehøy, B. Kjøllmoen, R.V. Engeset and N. Haakensen. 2005. Glacier mass balance and length variation in Norway. Ann. Glaciol., 42 (see paper in this volume).

Angell, J.K. 1988. Variations and trends in tropospheric and stratospheric global temperatures, 1958-87. J. Climate, 1(12), 1296-1313.

Arendt, A.A., K.A. Echelmeyer, W.D. Harrison, C.S. Lingle and V.B. Valentine. 2002. Rapid wastage of Alaska glaciers and their contribution to rising sea level. Science, 297(5580), 382-386.

Dyurgerov, M.B. and M.F. Meier. 2000. Twentieth century climate change: evidence from small glaciers. Proc. Nat. Acad. Sci., 97(4), 1406-1411.

Hagen, J.O. 1996. Recent trends in mass balance of glaciers in Scandinavia and Svalbard. Nat. Inst. Polar Res. Mem., Special Issue, 51, 349-354.

Hayes, P.S., L.A. Rasmussen and H. Conway. 2002. Estimating precipitation in the central Cascades of Washington. J. Hydrometeorol., 3(3), 335-346.

Holmlund, P. 1987. Mass balance of Storglaciären during the 20th century. Geogr. Ann., 69A(3-4), 439-447.

Holmlund, P., W. Karlén and H. Grudd. 1996. Fifty years of mass balance and glacier front observations at the Tarfala Research Station. Geogr. Ann., 78A(2-3), 105-114.

Hurrell, J.W. 1995. Decadal trends in the North Atlantic Oscillation: regional temperature and precipitation. Science, 269(5224), 676-679.

Jóhannesson, T., O. Sigurdsson, T. Laumann and M. Kennett. 1995. Degree-day glacier mass-balance modelling with applications to glaciers in Iceland, Norway and Greenland. J. Glaciol., 41(138), 345-358.

Jones, P.D., T. Jónsson and D. Wheeler. 1997. Extension to the North Atlantic Oscillation using early instrumental pressure observations from Gibraltar and South-West Iceland. Int. J. Climatol., 17, 1433-1450.

Kalnay, E. and 21 others. 1996. The NCEP/NCAR 40-year reanalysis project. Bull. Am. Meteorol. Soc., 77(3), 437-471.

Kistler, R. and 12 others. 2001. The NCEP/NCAR 50-year reanalysis: monthly means CD-ROM and documentation. Bull. Am. Meteorol. Soc., 82(2), 247-267.

Kjøllmoen, B. 2003. Glaciological investigations in Norway in 2001. Norwegian Water Resources and Energy Directorate Report 1.

Laumann, T. and N. Reeh. 1993. Sensitivity to climate change of the mass balance of glaciers in southern Norway. J. Glaciol., 39(133), 656-665.

Lie, Ø., S.O. Dahl and A. Nesje. 2003. A theoretical approach to glacier equilibrium-line altitudes using meteorological data and glacier mass-balance records from southern Norway. The Holocene, 13(3), 365-372.

Nesje, A., Ø. Lie and S.O. Dahl. 2000. Is the North Atlantic Oscillation reflected in Scandinavian glacier mass balance records? J. Quat. Sci., 15(6), 587-601.

Oerlemans, J. 1992. Climate sensitivity of glaciers in southern Norway: application of an energy-balance model to Nigardsbreen, Hellstugubreen and Alfotbreen. J. Glaciol., 38(129), 223-232. 
Oerlemans, J. and J.P.F. Fortuin. 1992. Sensitivity of glaciers and small ice caps to greenhouse warming. Science, 258(5079), 115-117.

Oerlemans, J. and B.K. Reichert. 2000. Relating glacier mass balance to meteorological data by using a seasonal sensitivity characteristic. J. Glaciol., 46(152), $1-6$.

Pohjola, V.A. and J.C. Rogers. 1997. Atmospheric circulation and variations in Scandinavian glacier mass balance. Quat. Res., 47(1), 29-36.

Rasmussen, L.A. and H. Conway. 2001. Estimating South Cascade Glacier (Washington, USA) mass balance from a distant radiosonde and comparison with Blue Glacier. J. Glaciol., 47(159), 579-588.
Rasmussen, L.A. and H. Conway. 2003. Using upper-air conditions to estimate South Cascade Glacier (Washington, USA) summer balance. J. Glaciol., 49(166), 456-462.

Rasmussen, L.A. and H. Conway. 2004. Climate and glacier variability in western North America. J. Climate, 17(9), 1804-1815.

Rasmussen, L.A., H. Conway and P.S. Hayes. 2001. Estimating Olympic Peninsula precipitation from upper-air wind and humidity. J. Geophys. Res., 106(D2), 1493-1501.

Rasmussen, L.A., H. Conway and C.F. Raymond. In press. Influence of upper air conditions on the Patagonia icefields. Global Planet. Change.

Thompson, D.W.J. and J.M. Wallace. 2000. Annular modes in the extratropical circulation. Part I: Month-to-month variability. J. Climate, 13(5), 1000-1016. 